\title{
BALANCE OF COST, TIME, AND QUALITY RELATED TO CONSTRUCTION PROJECTS REGARDING THE REINFORCED CONCRETE OF UNDERGROUND STRUCTURES USING A META-HEURISTIC ALGORITHM
}

\begin{abstract}
S. A. HOSSEINI ${ }^{1}$, A. AKBARPOUR ${ }^{* 2}$, H. AHMADI ${ }^{3}$, B. AMINNEJAD ${ }^{4}$
Underground spaces having features such as stability, resistance, and being undetected can play a key role in reducing vulnerability by relocating infrastructures and manpower. In recent years, the competitive business environment and limited resources have mostly focused on the importance of project management in order to achieve its objectives. In this research, in order to find the best balance among cost, time, and quality related to construction projects using reinforced concrete in underground structures, a multi-objective mathematical model is proposed. Several executive approaches have been considered for project activities and these approaches are analyzed via several factors. It is assumed that cost, time, and quality of activities in every defined approach can vary between compact and normal values, and the goal is to find the best execution for activities, achieving minimum cost and the maximum quality for the project. To solve the proposed multi-objective model, the genetic algorithm NSGA-II is used.
\end{abstract}

Keywords: Underground structures, Project management, Balance of cost, time, and quality, Meta-Heuristic, Genetic algorithm.

\footnotetext{
${ }^{1} \mathrm{PhD}$ candidate of Civil engineering, Roudehen branch, Islamic Azad University,Roudehen,Iran, e-mail: st.a.hosseini@riau.ac.ir

2 *PhD., Islamic Azad University, South Tehran Branch, Department of Civil Engineering, Tehran, Iran, e-mail: a akbarpour@azad.ac.ir

3 PhD., Islamic Azad University, Roudehen Branch, Department of Civil Engineering, Roudehen, Iran, e-mail: hgahmadi@riau.ac.ir

4 PhD., Islamic Azad University, Roudehen Branch, Department of Civil Engineering, Roudehen, Iran, e-mail: aminnejad@riau.ac.ir
} 


\section{INTRODUCTION}

Throughout human history, only a few years can be found in which no war has happened. With the adventing of mankind to an era of evolving technologies, not only this factor not decrease, but methods of warfare have changed in ways where losing hundreds of people has become possible in a fraction of a second, and these destructive events have occurred several times over the last century. Using underground spaces for a variety of applications can reduce vulnerability. Reinforced concrete of underground structures can absorb energy of explosions. By providing sufficient slag, increased safety can be created in these spaces. In this regard, an important advantage of embedded spaces in addition to heavy structure and soil cover, is its limited number of openings, entrances, and exits to the ground level. Therefore, underground spaces are valuable shelters in emergencies. Nowadays, even in countries with less probability of getting involved in a war, different applications of underground spaces are being exploited (Jalali and Hashemi Fesharaki [1]), (Asgharian Jedi [2]).

A safe space refers to a closed space which provides enough security for inner residents or facilities against various forms of attack. This space has its own specific requirements so it needs special architectural, structural, and infrastructural considerations of its own. Appropriate safe spaces must be able to resist wave blasts, quivers of classic weapons, penetration of heat, and also radiation effects of nuclear weapons and chemical gases. Naturally, obtaining such space requires considerable financial backing, expertise, and executional resources (Ghani [3]), (Nouroozi [4]).

The idea of constructing a safe space is to reduce or eliminate the effects of destruction and radiation due to classic (or nuclear) bombardment and special equipment. In air strikes, bombs with massive explosion and destructive power are usually used, and so through the collision of these bombs onto their targets, a very high level of kinetic energy is created. This kinetic energy propagates as pressure and heat in the environment which would disrupt and destroy the target. Occasionally, protection against bombings in buildings and facilities is provided by retrofitting against a direct hit. This is done for very important spaces such as command posts and vital infrastructures. However, in other cases, this is unreasonable from an economical perspective, so buried or semi-buried safe spaces are often used (Movahedinia [5]). In Table 1, advantages and disadvantages of using underground spaces are presented. Classification of underground space applications is presented in Table 2. The sample examined in this study is an infrastructure type. The information given in Tables 1 and 2 is about the introduction of underground structures. 
Table 1. advantages and disadvantages of using underground spaces (Sterling and Carmody [6]).

\begin{tabular}{|c|c|c|c|}
\hline Category & Application & Potential Benefits & Potential Problems \\
\hline \multirow{17}{*}{ 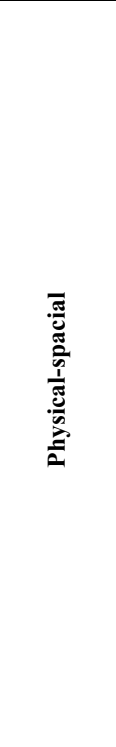 } & \multirow{4}{*}{ Localization } & \multicolumn{2}{|l|}{ Proximity (nearby facilities) } \\
\hline & & The lack of space on the surface & Bad geological conditions \\
\hline & & Service providing by saving on the & Unknown geology and execution problems \\
\hline & & ground space & \\
\hline & & Climate Protection (heat, cold and & \\
\hline & & etc) & Climatic issues in very hot or very humid areas \\
\hline & Segregation & Protection (noise, vibration, blast, air & Communication problems \\
\hline & & pollution) & Human issues \\
\hline & \multicolumn{3}{|c|}{ Security } \\
\hline & \multirow{4}{*}{ Protection } & No effects on urban landscape & Aesthetics (no exterior, attention and skill in \\
\hline & & Environmental issues (maintaining & interior design) \\
\hline & & landscapes, natural ecology and etc) & Environmental issues (ecological damage when \\
\hline & & The interior design is highlighted & drilling and construction, drainage problem) \\
\hline & \multirow{4}{*}{ Outline } & \multirow{4}{*}{$\begin{array}{l}\text { Free from ground topographic } \\
\text { constraints and nearby facilities }\end{array}$} & Design limitations due to columns, number of \\
\hline & & & required entries and etc \\
\hline & & & Limited access \\
\hline & & & Garbage and waste transfer problems \\
\hline \multirow{11}{*}{ 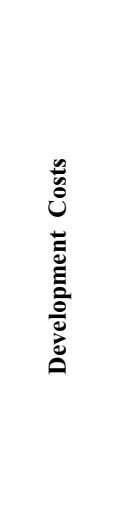 } & \multirow{6}{*}{ Initial costs } & Cost reduction of providing the land & $\mathrm{n}$ \\
\hline & & Savings in the costs of construction & Limited access \\
\hline & & censing & Excavation and removal of materials \\
\hline & & & Construction delays due to unexpected \\
\hline & & 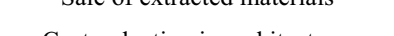 & obstacles \\
\hline & & Cost reduction in architecture, & High maintenance costs \\
\hline & & Stable environmental conditions and & Costly ventilation and lighting \\
\hline & & lack of erosion & More difficult access to the facilities in order to \\
\hline & & Reduced insurance costs due to the & repair \\
\hline & & more established protection & The high cost of maintenance compared to on \\
\hline & & Reduced energy consumption & the ground spaces \\
\hline & & Efficiency in land use & \\
\hline & & Efficiency of the transport system & Environmental problems (drainage, waste \\
\hline$\stackrel{\mathscr{g}}{0}$ & & Energy savings & disposal and pollution penetration) \\
\hline 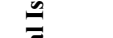 & & More preparedness against disasters & The impossibility of changing the application \\
\hline 䒕 & & Providing better security & and different forms of facilities \\
\hline & & Construction with less damage to the & High energy consumption during construction \\
\hline & & environment & \\
\hline
\end{tabular}


Table 2. Classification of underground space applications

\begin{tabular}{ccc}
\hline Categories & Human use & Production use \\
\hline Residential & Single-family & \\
& Multi-families & \\
\hline Leligious & Industrial \\
Non- & Cultural & Parking \\
residential & Administrative & Warehousing \\
& Commercial & Agricultural \\
& Health care facilities & Transportation of goods \\
& & Public facilities \\
Infrastructure & Energy \\
& Transportation of passengers & Consumption \\
& & Mines \\
\hline Military & Defense & Military installations \\
& & Hangar of airplanes \\
& & Arsenal \\
& & Data center \\
\hline
\end{tabular}

Project management is an organized system for the management of resources, so that the project is completed with a certain clear vision and meets the requirements of quality, time, and cost (Burke [7]). Construction projects, like any other activities and projects, have their own limitations. In project management, traditionally, these limitations are scope, time, and cost. These three factors are also referred to as the project management triangle, in which each limitation represents one side of the triangle. As in geometry; if one side changes, the remaining sides change too, showing that in project management any variation of a given factor effects other factors as well. The project management triangle can also be used for relationships between time, cost, and quality (Clements and Gido [8]). The project triangle shown in Fig. 1, means that every project has three constraints which are time, cost, and scope. 


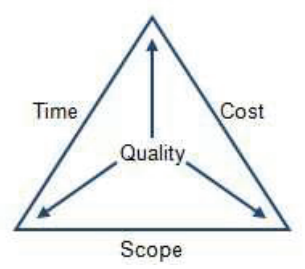

Fig .1- Project management triangle

The balance between cost, time, and quality is one of the most important issues in project management and contractor interest in the project. The main objective of balancing the time and cost of a project is to analyze the sensitivity of project costs in regards to changes of the duration related to activities in order to obtain the best combination of the duration of activities in a way that minimizes total project costs, including direct costs and indirect costs (Zheng and Mao [9]). In fact, the balancing models of time and cost are searching for solutions as optimum allocation of resources to activities, so that in each of these solutions time and costs are minimized (Vanhoucke and Debels [10]).

In general, the issue of balancing cost, time, and quality simultaneously tries to consider three important factors in project management. It is easy to understand that this issue is a multi-objective one at the essence and can be modeled in the form of multi-objective models (Shuquan and Kongguo [11]). The structure of such a model includes a number of options for each activity, and the model tries to choose the ones with minimum costs and time and highest quality, but a balancing takes place for this selection, since high quality and speed come with a price, and execution of a costly project might not be possible. This research tries to model the problem of balancing cost, time, and quality in the form of a multi-objective problem and then solve it using meta-heuristic algorithms.

\section{THEORETICAL FOUNDATIONS}

Balance of Time, Cost, and Quality: The balancing models of time and cost are trying to find optimum solutions for allocations of resources to activities so that in each of these solutions time and costs are minimized. A project should be planned according to its resources. The duration of an activity can be considered as a function of available resources. Also, the quality of the project is 
somehow a function of time and cost, and in addition, different sources have different costs and qualities. In general, the balance of these three factors tries to consider three important issues at the same time in project management. It easily can be seen that at the essence, this issue is a multiobjective one and in the end the project planner/manager must balance all three factors of the project (Assadipour and Iranmanesh [12]).

Genetic Algorithm: In this algorithm, past data is used based on its hereditary nature. In the mathematical model of genetic methods, all genetic operators are simulated and their combinations identify a natural process of selecting the best solution. In this method, a sample of all the variables related to decision-making influencing the objective function are considered as a member, whereas some of these samples form a set of members called "sample population" in the variables of space. Then, by executing genetic operators on members and the initial population, a new generation with better merit is created. Repeating this process over and over over several generations will result in the most qualified generation; the optimal solution. By mathematically simulating and evolving genetic operators in a comprehensive search on a range of solutions during a series of generations, the most perfect sample is obtained giving the best optimization of the objective function meeting limitations (Deb, et al. [13]).

\section{BACKGROUND OF RESEARCH}

In recent decades, various methods related to optimizing the combination of time, cost, and quality of projects have been introduced. Considering quality as an optimization target in selecting executive methods of projects has become the center of attention. Most of the articles have been dedicated to the optimization of time and cost simultaneously. Surveys have shown that the issue of balance between the main criteria of a project, which was first brought up in 1961 and was related to two factors - time and cost, was gradually considered in projects by the emerging of quality in modern engineering contracts, the balancing of time and quality costs.

The proposed methods in projects related to optimization of the three factors mentioned above in executive projects can generally be categorized into three groups; heuristic, mathematical, and meta-heuristic. The Fondahl method (Fondahl [14]), a structural method of computing project cost by Prager (Prager [15]), and a hardship method by Moslehi (Moselhi [16]) are among heuristic the methods used. The linear planning method by Kelley (Kelley Jr [17]), a linear planning method by Hendrickson (Hendrickson and Au [18]), a linear planning method by Pagnoni (Pagnoni [19]), an 
integer planning method by Patterson (Patterson and Huber [20]), and a combined linear planning method by Liu et. Al. (Liu and Rahbar [21]) are among the mathematical methods proposed by researchers in which the issue of time and cost balance is optimized by a single mathematical model.

Fennec et. Al. (Feng, et al. [22]) proposed a combined approach using a genetic algorithm and a simulation method to solve the problem of balancing time and cost under uncertainty. Yang (Yang [23]) used the dispersed particles algorithm for solving the problem of balancing the three factors mentioned previously. The objective function of this algorithm is defined as a multi-attribute desirability function, and grid computing is done by the critical path method.

Hong-mei et. al. (Hong-mei, et al. [24]) used a self-regulating ant colony algorithm in order to solve the balancing of time and cost discretely. Irregularities investigation is used to control ant colony algorithm factors and thereby prevents the premature convergence of it.

Assadipour (Assadipour and Iranmanesh [12]) presented a multi-objective meta-heuristic method to solve the problem of balance between time, cost, and quality. The mentioned algorithm, which is a cell composition genetic one and is an optimization method, tries to obtain a set of optimized Pareto answers in which the best possible schedule is achieved, and any change in this schedule to achieve a better answer in the three factors mentioned previously will results in adverse changes in the other Paretos.

Jolai et. Al. (Jolai and Assadipour [25]) have presented a meta-heuristic algorithm based on a genetic algorithm to solve a multi-objective scheduling problem looking for the Pareto boundary point in time, cost, and quality. The mentioned algorithm is a developed algorithm based on an edition of a genetic algorithm which is used for multi-objective problems.

Shrivastava (Shrivastava, et al. [26]) used the multi-objective ant colony algorithm for solving the problem of balancing time and cost. To assign weight factors to routes, a modified adaptive weighting method is used, so that gradually, by finding answers, the Pareto boundary is formed.

\section{Multi-ObJective Mathematical Model of Balancing Cost, TIME AND QUALITY}

The model presented in this section is based on integer planning. In this model, several executive methods based on the combination of materials and labor are possible for each activity and these different executive methods will have different times, costs and quality. 


\subsection{MODEL INDICES}

Indices that have been used in the model are presented in Table 3.

Table 3. Model Indices

\begin{tabular}{ccc}
\hline Index & Character & Counters \\
\hline Project Events & $\mathrm{m}$ & $1,2, \ldots, \mathrm{i}, \mathrm{j}, \ldots, \mathrm{M}$ \\
\hline Activities in the graph & $\mathrm{n}$ & $1,2, \ldots, \mathrm{N}$ \\
\hline $\begin{array}{c}\text { Combination of activities and human } \\
\text { resource for each activity }\end{array}$ & $\mathrm{k}$ & $1,2, \ldots, \mathrm{K}$ \\
\hline
\end{tabular}

\subsection{Model Parameters}

Parameters that have been used in the model are presented in Table 4.

Table 4. Model Parameters

\begin{tabular}{|c|c|}
\hline Parameter & Description \\
\hline $\mathrm{nt}_{\mathrm{ijk}}$ & normal time of activity $\mathrm{ij}$, if using combination $\mathrm{k}$ of materials and human resources \\
\hline $\mathrm{nc}_{\mathrm{ijk}}$ & normal cost of activity $\mathrm{ij}$, if using combination $\mathrm{k}$ of materials and human resources \\
\hline $\mathrm{nq}_{\mathrm{ijk}}$ & normal quality of activity ij, if using combination $\mathrm{k}$ of materials and human resources \\
\hline $\mathrm{ct}_{\mathrm{ijk}}$ & intensive time of activity $\mathrm{ij}$, if using combination $\mathrm{k}$ of materials and human resources \\
\hline $\mathrm{cc}_{\mathrm{ijk}}$ & intensive price of activity $\mathrm{ij}$, if using combination $\mathrm{k}$ of materials and human resources \\
\hline $\mathrm{cq}_{\mathrm{ijk}}$ & intensive quality of activity $\mathrm{ij}$, if using combination $\mathrm{k}$ of materials and human resources \\
\hline $\mathrm{A}_{\mathrm{ijk}}$ & $\begin{array}{l}\text { activity ij's width from origin of time changes vs. costs line, if using combination k of } \\
\text { materials and human resources }\end{array}$ \\
\hline $\mathrm{A}^{\prime} \mathrm{ijk}$ & $\begin{array}{l}\text { activity ij's width from origin of time changes vs. quality line, if using combination } \mathrm{k} \text { of } \\
\text { materials and human resources }\end{array}$ \\
\hline $\mathrm{B}_{\mathrm{ijk}}$ & $\begin{array}{l}\text { gradient of activity ij's time changes vs. costs line, if using combination k of materials and } \\
\text { human resources }\end{array}$ \\
\hline $\mathrm{B}_{\mathrm{ijk}}$ & $\begin{array}{l}\text { gradient of activity ij's time changes vs. quality line, if using combination k of materials and } \\
\text { human resources }\end{array}$ \\
\hline UT, UC & upper limit for the project time and project cost \\
\hline LQ & bottom limit for the project quality \\
\hline $\mathrm{PT}, \mathrm{PC}, \mathrm{PQ}$ & project time, project cost and project quality \\
\hline
\end{tabular}




\subsection{MODEL VARIABLES}

Decision variables are presented in Table 5 .

Table 5. Model Variables

\begin{tabular}{cc}
\hline Variable & Description \\
\hline $\mathrm{Y}_{\mathrm{i}}$ & the earliest possible time for the event $\mathrm{i}$ \\
\hline $\mathrm{X}_{\mathrm{ijk}}$ & $\begin{array}{r}\text { duration of activity ij, if using combination } \mathrm{k} \text { of materials and human } \\
\text { resources which is selected as optimization variable by the model }\end{array}$ \\
\hline $\mathrm{Z}_{\mathrm{ijk}}$ & $\begin{array}{r}\text { zero or one variable, takes one if combination } \mathrm{k} \text { of materials and human } \\
\text { resources is used for activity ij and takes zero otherwise }\end{array}$ \\
\hline
\end{tabular}

\subsection{OBJECTIVE FunCTIONS}

Being a triple-objective model, three objective functions are defined as below:

$$
\begin{gathered}
\text { Min } \mathrm{PT}=Y_{M} \\
\operatorname{Min} \mathrm{PC}=\sum_{i j} \sum_{k} Z_{i j k}\left(A_{i j k}-B_{i j k} X_{i j k}\right) \\
\operatorname{Max} \mathrm{PQ}=\sum_{i j} \sum_{k} Z_{i j k}\left(A_{i j k}^{\prime}+B_{i j k}^{\prime} X_{i j k}\right) / N
\end{gathered}
$$

As it can be seen, the first objective function of the project is equal to the last event that should be minimized. The second objective function is the total costs of the project that should be minimized. The third objective function shows the average quality of the project that should be maximized.

\subsection{Model Constraints}

Model limitations include:

$$
Y_{1}=0
$$

This limitation shows that opening event time of the project is equal to zero.

$$
Z_{i j k} \times c t_{i j k} \leq X_{i j k} \leq Z_{i j k} \times n t_{i j k} \quad \forall i, j, k
$$


The above constraints show that the duration of an activity with a certain combination of materials and human resources should be between the normal and intensive value of it, if selected.

$$
Y_{i}+X_{i j k} Z_{i j k}-Y_{j} \leq 0 \quad \forall i, j, k
$$

The above constraints show the relationships between the time of each activity and duration of it so that the final time is obtained by adding duration to the initial time.

$$
\sum_{k} Z_{i j k} \geq 1 \quad \forall i, j
$$

The above constraints show how the $k$ different combinations is checked between $i$ and $j$ groups. As it can be seen, activity between two groups can be done with different execution methods, with different material, or even with different skill levels of manpower.

$$
\begin{aligned}
B_{i j k}=\frac{\left(c c_{t j k}-n c_{i j k}\right)}{\left(n t_{i j k}-c t_{i j k}\right)} & \forall i, j, k \\
B^{\prime}{ }_{i j k}=\frac{\left(n q_{i j k}-c q_{i j k}\right)}{\left(n t_{i j k}-c t_{i j k}\right)} & \forall i, j, k
\end{aligned}
$$

The above constraints calculate a gradient of time vs. cost and time vs. quality lines, respectively.

$$
\begin{aligned}
A_{i j k}=c c_{i j k}+B_{i j k} c t_{i j k} & \forall i, j, k \\
A^{\prime}{ }_{t j k}=c q_{i j k}-B^{\prime}{ }_{l j k} c t_{l j k} & \forall i, j, k
\end{aligned}
$$

The above constraints calculate width from origin of time vs. cost and time vs. quality lines, respectively.

$$
\begin{gathered}
X_{i j k} \geq 0 \quad \forall i, j, k \\
Z_{i j k} \in\{0,1\} \quad \forall i, j, \mathrm{k}
\end{gathered}
$$

The above constraints show that the duration of each activity equals to or is greater than zero and variable $Z_{i j k}$ should be zero or one. 


\section{IMPLEMENTATION}

In order to use the model, it has to be implemented, so as a case study a plan to build a secure underground space is studied. Construction plans regarding reinforced concrete use in underground structures include the planning and design stages before the execution stage starts.
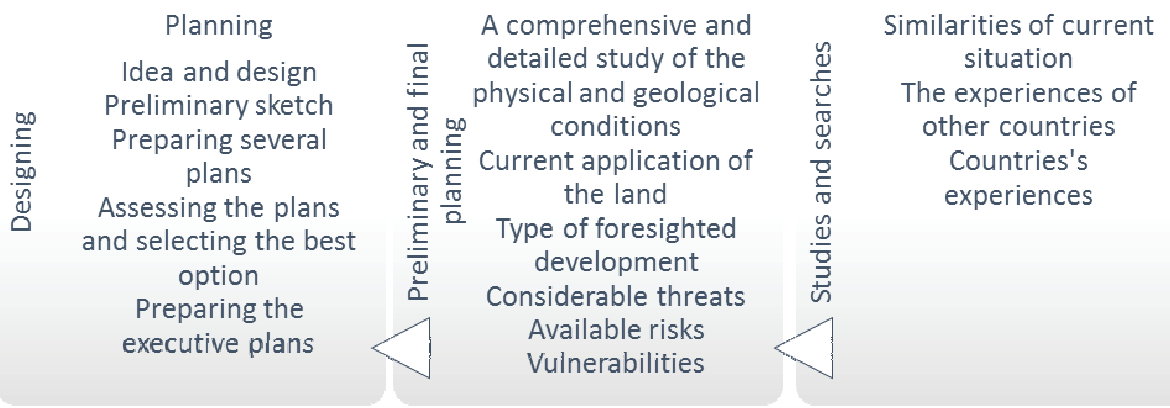

Fig. 2- Process planning construction related to reinforced concrete use in underground structures before the execution of plan

The items concerning reinforced concrete of an underground structure's construction plan (studies) are presented in Table 6.

Table 6. Planning items related to reinforced concrete of underground structure's construction project

\begin{tabular}{|c|c|}
\hline Definitions and general goals & $\begin{array}{l}\text { Definition, over view of activity about underground structure, design character, } \\
\text { main goal of plan, construction cost }\end{array}$ \\
\hline Project components & $\begin{array}{l}\text { Introducing areas, sectors and how they relate, introducing spaces and some } \\
\text { coordinates of them }\end{array}$ \\
\hline Outdoor components & Arranging of spaces \\
\hline Threats and dangers & $\begin{array}{l}\text { Explaining the threats, their effects and consequences, possible risk analysis } \\
\text { (risk) }\end{array}$ \\
\hline Plan and Location & $\begin{array}{l}\text { Plan and ground, plan and proximities, plan and environmental structure, } \\
\text { plan and other geological factors }\end{array}$ \\
\hline Development plan & Future needs, change of application \\
\hline Building technology & $\begin{array}{l}\text { Construction method, type ofmaterials, type of structure, the resistance against } \\
\text { explosive loads }\end{array}$ \\
\hline Construction cost & $\begin{array}{l}\text { The cost of different sectors, benefit-cost ratio of immunization and reducing } \\
\qquad \text { vulnerability, total cost }\end{array}$ \\
\hline Construction schedule & Duration of construction in different stages, reducing construction's duration \\
\hline
\end{tabular}


secure underground space on a large scale are categorized as follows: Access, inputs and outputs, Ergonomics, Autonomy of secure space, Ability to be restored, Safe systems of fire extinguish, Executive details, Ventilation and filtration, Interior architectural design and Structure.

Activities related to the construction project of a secure underground space are presented in Table 7 .

Fig. 3 also shows a graph of project activities.

Table 7. Description of project activities related to a construction plan of a secure underground space

\begin{tabular}{|c|c|c|}
\hline \multirow{2}{*}{$\begin{array}{l}\text { Activity } \\
\text { No. }\end{array}$} & \multicolumn{2}{|c|}{ Description of Activity } \\
\hline & Construction mode 1 & Construction mode 2 \\
\hline 1 & $\begin{array}{l}\text { Constructing of areas, sectors and how they } \\
\text { relate, standard arranging of spaces, } \\
\text { construction of nearby and neighborhood-like } \\
\text { designing of areas }\end{array}$ & $\begin{array}{l}\text { Constructing of areas, sectors and how they } \\
\text { relate, special arranging of spaces, } \\
\text { construction of nearby and neighborhood-like } \\
\text { designing of areas in detail }\end{array}$ \\
\hline 2 & $\begin{array}{l}\text { Constructing the plan in accordance with } \\
\text { standard codes and special requirements }\end{array}$ & $\begin{array}{c}\text { Designing, constructing and using the plan in } \\
\text { accordance with specific codes and special } \\
\text { requirements }\end{array}$ \\
\hline 3 & $\begin{array}{l}\text { Designing standard accesses, entrances and } \\
\text { exits }\end{array}$ & $\begin{array}{l}\text { Designing specific accesses, entrances and } \\
\text { exits, anticipated surge arrester, consolidation } \\
\text { of entrances and exits and providing enough } \\
\text { slag }\end{array}$ \\
\hline 4 & $\begin{array}{l}\text { Construction of structural design, able to resist } \\
\text { service loads and accidental events }\end{array}$ & $\begin{array}{l}\text { Construction of structural design, secure } \\
\text { underground space requirements, resistant } \\
\text { against explosive loads }\end{array}$ \\
\hline 5 & Constructing standard details & $\begin{array}{l}\text { Constructing specific details and resistant } \\
\text { against explosive loads }\end{array}$ \\
\hline 6 & $\begin{array}{l}\text { Construction with standard materials, lower } \\
\text { retrofitting capability }\end{array}$ & $\begin{array}{l}\text { Construction with special materials, } \\
\text { construction of special reinforced concrete } \\
\text { structure, high retrofitting capability }\end{array}$ \\
\hline 7 & Typical doors and windows & $\begin{array}{l}\text { High strength and anti-explosion doors and } \\
\text { windows }\end{array}$ \\
\hline 8 & Standard interior design & $\begin{array}{l}\text { Special interior design in accordance with } \\
\text { psychological effects of safe underground } \\
\text { spaces }\end{array}$ \\
\hline 9 & $\begin{array}{l}\text { Ventilation and filtration and creation of } \\
\text { favorable security }\end{array}$ & $\begin{array}{l}\text { Ventilation and filtration and creating safe } \\
\text { space }\end{array}$ \\
\hline 10 & $\begin{array}{c}\text { Implementing requirements of secure } \\
\text { underground space with limited autonomy }\end{array}$ & $\begin{array}{l}\text { Dual application of underground space and } \\
\text { full autonomy of secure underground space }\end{array}$ \\
\hline
\end{tabular}




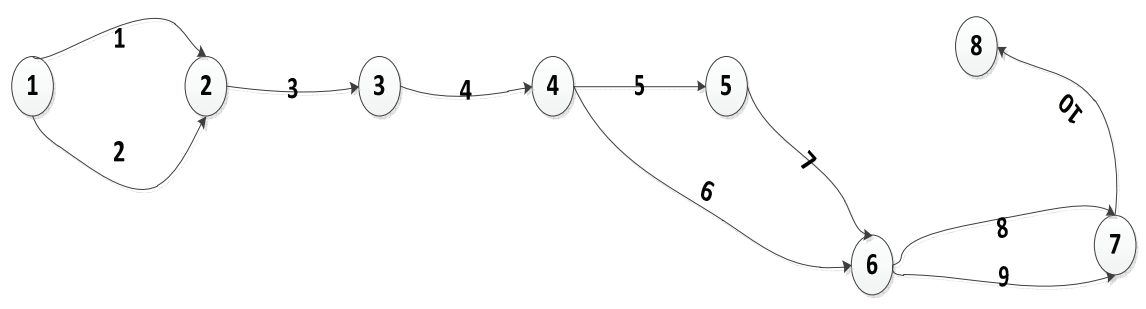

Figure 3. Graph of activities related to a construction project in a secure underground space

\subsection{Estimating the ReQuired Model Parameters}

In order to establish a model to optimize the balance of cost, time, and quality, normal and intensive values of these parameters should be estimated. Also, all intensive forms of activities that are available should be determined. For this purpose, a group of five construction experts is used to determine several execution methods for activities mentioned in Table 2, and for each methodparameters related to normal and intensive values of time, cost, and quality are determined. By holding several meetings and interviews with the experts, data present in Table 8 was collected.

Table 8. Intensive and normal cost, time, and quality of activities in different construction modes

\begin{tabular}{cccccccc}
\hline \multirow{2}{*}{$\begin{array}{c}\text { Activity } \\
\text { No. }\end{array}$} & $\begin{array}{c}\text { Construction } \\
\text { mode }\end{array}$ & \multicolumn{3}{c}{ Normal } & \multicolumn{3}{c}{ Intensive } \\
\cline { 2 - 8 } 1 & 1 & Time & Cost & Quality & Time & Cost & Quality \\
\cline { 2 - 8 } & 2 & 90 & 71 & 1 & 74 & 80 & 0.91 \\
\hline \multirow{2}{*}{2} & 1 & 90 & 77 & 1 & 85 & 82 & 0.95 \\
\hline \multirow{2}{*}{3} & 2 & 74 & 82 & 1 & 70 & 90 & 0.82 \\
\hline \multirow{2}{*}{4} & 1 & 50 & 45 & 1 & 42 & 52 & 0.76 \\
\hline \multirow{2}{*}{5} & 2 & 39 & 50 & 1 & 30 & 56 & 0.88 \\
\hline & 1 & 30 & 38 & 1 & 25 & 46 & 0.85 \\
\hline 6 & 2 & 25 & 43 & 1 & 20 & 46 & 0.77 \\
\hline & 1 & 20 & 27 & 1 & 14 & 40 & 0.72 \\
\hline & 2 & 30 & 33 & 1 & 27 & 38 & 0.80 \\
\hline
\end{tabular}




\begin{tabular}{cccccccc}
\hline 7 & 1 & 20 & 18 & 1 & 18 & 22 & 0.91 \\
\cline { 2 - 8 } & 2 & 17 & 24 & 1 & 14 & 29 & 0.92 \\
\hline \multirow{2}{*}{8} & 1 & 40 & 61 & 1 & 32 & 70 & 0.89 \\
\cline { 2 - 8 } 9 & 2 & 30 & 70 & 1 & 23 & 81 & 0.79 \\
\hline \multirow{2}{*}{10} & 1 & 30 & 28 & 1 & 27 & 39 & 0.82 \\
\cline { 2 - 7 } & 2 & 23 & 36 & 1 & 19 & 43 & 0.86 \\
\hline
\end{tabular}

Using the mathematical model described in the previous section and the estimated parameters from Table 1, a multi-objective mathematical model to optimize the balance of cost, time, and quality is developed.

In order to solve the model, the meta-heuristic algorithm NSGA-II is used and for that purpose mathematical computation and programming software, MATLAB, is utilized. After completing the computation and modeling code by using a computer system with an Intel Core i7 processor and $8 \mathrm{~GB}$ of RAM, after 1500 iterations in over 28 minutes optimization results are obtained - presented in Table 9.

Table 9. Results of the model using genetic algorithm NSGA-II

\begin{tabular}{|c|c|c|c|c|}
\hline \multirow{2}{*}{ Activity No. } & \multirow{2}{*}{$\begin{array}{c}\text { Construction } \\
\text { mode }\end{array}$} & \multicolumn{3}{|c|}{ Optimal Answer } \\
\hline & & Time & Cost & Quality \\
\hline \multirow{2}{*}{1} & 1 & 87 & 112.50 & 0.89 \\
\hline & 2 & - & - & - \\
\hline \multirow{2}{*}{2} & 1 & - & - & - \\
\hline & 2 & 71 & 88.00 & 0.87 \\
\hline \multirow{2}{*}{3} & 1 & 45 & 49.38 & 0.85 \\
\hline & 2 & - & - & - \\
\hline \multirow{2}{*}{4} & 1 & 25 & 46.00 & 0.85 \\
\hline & 2 & - & - & - \\
\hline \multirow{2}{*}{5} & 1 & - & - & - \\
\hline & 2 & 18 & 31.33 & 0.91 \\
\hline \multirow{2}{*}{6} & 1 & - & - & - \\
\hline & 2 & 20 & 41.00 & 0.87 \\
\hline \multirow{2}{*}{7} & 1 & 18 & 22.00 & 0.91 \\
\hline & 2 & - & - & - \\
\hline 8 & 1 & - & - & - \\
\hline
\end{tabular}




\begin{tabular}{ccccc}
\hline & 2 & 27 & 74.71 & 0.91 \\
\hline \multirow{2}{*}{9} & 1 & - & - & - \\
\cline { 2 - 5 } & 2 & 22 & 37.75 & 0.97 \\
\hline \multirow{2}{*}{10} & 1 & 25 & 47.83 & 0.93 \\
\cline { 2 - 5 } & 2 & - & - & - \\
\hline SUM & & 358 & 550.50 & 0.896
\end{tabular}

The results of the model indicate that mode 1 is selected for the first activity, and based on the results it should be planned in a way where the activity is completed in 87 days, at the expense of 112.5 monetary units and with $89 \%$ quality, compared to the best possible quality. For the second activity, the second executive mode is selected as the optimum mode, and in this case the optimal time is 71 days, at a cost of 88 units and $87 \%$ quality when compared to ideal quality. Also, according to the results, the total duration of the project is 358 days, the total project cost is 550 monetary units, and the average quality of the project activities is $90 \%$.

\section{Conclusion}

Infrastructure projects require high amounts of resources and cost. A prerequisite for the success of any project is to meet certain values for the three factors of time, cost, and quality, which means finishing at a certain time, with a certain cost, and a certain quality and straying from these limits could lead to failure. To obtain an optimal balance between these three factors of a project, mathematical modeling was used in this study; a multi-objective model with three main objectives. The first objective is to minimize the time of the project or the project duration. The second objective is to minimize the total cost of the project, and the third one is to maximize the quality of the project.

The result of using such a model shows that for some activities the first execution mode and for others the second execution mode is selected, and the optimal time for each action is obtained, remaining between normal and intensive value.

According to the results of this study, these areas of focus are suggested for future research:

- Use of newer and more efficient meta-heuristic algorithms in order to achieve shorter durations in solving the problem and calculating the code, e.g. the powerful Pareto evolutionary algorithm SPEA-II

- Optimizing time, cost, and quality of projects with EPC contracts. 


\section{REFERENCES}

[1] G. Jalali and S. J. Hashemi Fesharaki, "passive defense in terms of laws and regulations," ed. Passive Defense Organization, Tehran, 2010.

[2] A. Asgharian Jedi, " architectural requirements in sustainable civil defense," ed. martyr Beheshti University, 2007.

[3] A. Ghani, "patterns of passive defense of industrial and research centers according to the terms of war and peace and land use," ed: Aerospace Industries Organization, Institute of martyr Chamran doctor, Tehran, 2006.

[4] M. T. Nouroozi, " defensive security culture, Tehran," ed, 2006.

[5] J. Movahedinia, "The fundamentals of passive defense," ed: Third Edition, Tehran's Malek Ashtar University, 2009.

[6] R. L. Sterling and J. Carmody, "The experience with innovative underground structures at the University of Minnesota. Proc.," presented at the Int. Symp. On Unique Underground Structures, Denver, Colo, Golden , Colo: CSM Press, Colorado School of Mines, 1990.

[7] R. Burke, "Project management: planning and control techniques," ed. New Jersey, USA, 2013.

[8] J. P. Clements and J. Gido, "Effective project management," ed: Evans Publishing Group 2008.

[9] X. Zheng and Q. Mao, "Construction time-cost-cost trade-off based on genetic algorithms under resource restriction. In Communication Systems, Networks and Applications (ICCSNA)," in Second International Conference on IEEE, 2010, pp. 188-191.

[10] M. Vanhoucke and D. Debels, "The discrete time/cost trade-off problem: extensions and heuristic procedures," Journal of Scheduling, vol. 10, pp. 311-326, 2007.

[11]L. Shuquan and Z. Kongguo, "Research on multi-objective Optimization of lean construction project. In MultiMedia and Information Technology," in MMIT'08, International Conference on IEEE, 2008, pp. 480-483.

[12] G. Assadipour and H. Iranmanesh, "The discreet time, cost and cost trade-off problem in project scheduling: an efficient solution method based on CellDE algorithm: general articles," South African Journal of Industrial Engineering, vol. 21, pp. 93-101, 2010.

[13]K. Deb, A. Pratap, S. Agarwal, and T. A. M. T. Meyarivan, "A fast and elitist multiobjective genetic algorithm: NSGA-II. ," IEEE Transactions vol. 6, pp. 182-197, 2002.

[14]J. W. Fondahl, "A non-computer approach to the critical path method for the construction industry," 1962.

[15] W. Prager, "A structural method of computing project cost polygons," Management Science, vol. 9, pp. 394404, 1963.

[16] O. Moselhi, "Schedule compression using the direct stiffness method," Canadian Journal of Civil Engineering, vol. 20, pp. $65-72,1993$

[17] J. E. Kelley Jr, "Critical-path planning and scheduling: Mathematical basis.," Operations research, vol. 9, pp. 296-320, 1961.

[18]C. Hendrickson and T. Au, "Project management for construction: Fundamental concepts for owners, engineers, architects, and builders," Chris Hendrickson, 1989.

[19]A. Pagnoni, "Project engineering: computer-oriented planning and operational decision making," Springer Science \& Business Media, 2012.

[20] J. H. Patterson and W. D. Huber, "A horizon-varying, zero-one approach to project scheduling," Management Science, vol. 20, pp. 990-998, 1974.

[21]J. Liu and F. Rahbar, "Project time-cost trade-off optimization by maximal flow theory," Journal of construction engineering and management, vol. 130, pp. 607-609, 2004.

[22]C. W. Feng, L. Liu, and S. A. Burns, "Stochastic construction time-cost trade-off analysis," Journal of Computing in Civil Engineering, vol. 14, pp. 117-126, 2000.

[23]I. T. Yang, "Using elitist particle swarm optimization to facilitate bicriterion time-cost trade-off analysis," Journal of construction engineering and management, vol. 133, pp. 498-505, 2007.

[24]L. Hong-mei, W. Zhuo-fu, and L. Hui-min, "Artificial bee colony algorithm for real estate portfolio optimization based on cost preference coefficient," in In Management Science and Engineering (ICMSE), International Conference on IEEE, 2010.

[25]F. Jolai and G. Assadipour, "A hybrid cellular genetic algorithm for multi-objective crew scheduling problem," In Hybrid Artificial Intelligence Systems, Springer Berlin Heidelberg, pp. 359-367, 2010.

[26]R. Shrivastava, S. Singh, and G. C. Dubey, "Multi objective optimization of time cost cost quantity using multi colony ant algorithm," International Journal of Contemporary Mathematical Sciences, vol. 7, pp. 773-784, 2012. 


\section{LIST OF FIGURES AND TABLES:}

Table 1. advantages and disadvantages of using underground spaces (Sterling and Carmody [6]).

Tabela 1. Zalety i wady stosowania przestrzeni podziemnych (Sterling i Camody [6]).

Table 2. Classification of underground space applications.

Tabela 2. Klasyfikacja zastosowań przestrzeni podziemnych.

Table 3. Model Indices.

Tabela 3. Wskaźniki modelowe.

Table 4. Model Parameters.

Tabela 4. Parametry modelu.

Table 5. Model Variables.

Tabela 5. Zmienne modelu.

Table 6. Planning items related to reinforced concrete of underground structure's construction project.

Tabela 6. Planowanie elementów związanych z żelbetowym projektem budowy konstrukcji podziemnej.

Table 7. Description of project activities related to construction plan of a secure underground space.

Tabela 7. Opis działań projektowych związanych z planem budowy bezpiecznej przestrzeni podziemnej.

Table 8. Intensive and normal Cost, time and quality of activities in different construction modes.

Tabela 8. Intensywne i normalne koszty, czas i jakość działań w różnych trybach budowlanych.

Table 9. Results of the model using genetic algorithm NSGA-II.

Tabela 9. Wyniki modelu z użyciem algorytmu genetycznego NSGA-II.

Fig 1. Project management triangle.

Rys. 1. Trójkąt zarządzania projektem.

Fig. 2- Process about planning the construction related to reinforced concrete of underground structures before the execution of plan.

Rys. 2. Proces planowania konstrukcji związanej z zastosowaniem żelbetu w konstrukcjach podziemnych przed realizacją planu.

Figure 3. Graph of activities related to construction project in a secure underground space.

Rys. 3. Wykres działań związanych z projektem budowlanym w bezpiecznej przestrzeni podziemnej. 


\section{BILANS KOSZTÓW, CZASU I JAKOŚCI W ODNIESIENIU DO PROJEKTÓW BUDOWLANYCH DOTYCZĄCYCH BETONU ZBROJONEGO W KONSTRUKCJACH PODZIEMNYCH Z WYKORZYSTANIEM ALGORYTMU META-HEURYSTYCZNEGO}

Słowa kluczowe: Konstrukcje podziemne, zarządzanie projektem, bilans kosztów, czasu i jakości, algorytm metaheurystyczny, algorytm genetyczny

\section{STRESZCZENIE:}

Pomysł stworzenia bezpiecznej przestrzeni ma na celu zmniejszenie lub wyeliminowanie skutków zniszczenia i promieniowania, ze względu na bombardowanie klasyczne lub jądrowe i inne ataki. W przypadku ataków lotniczych zwykle używa się bomb z ogromnym potencjałem wybuchu i siłą niszczycielską, a zatem zderzenie tych bomb z celami powstaje bardzo wysoki poziom energii kinetycznej. Ta energia kinetyczna rozchodzi się jako ciśnienie i ciepło w środowisku, co może zakłócić i zniszczyć cel. Czasem ochrona przed bombardowaniami w budynkach i obiektach jest zapewniona przez modernizację zapobiegającą bezpośredniemu uderzeniu. Odbywa się to w przypadku ważnych miejsc, takich jak stanowiska dowodzenia i kluczowe elementy infrastruktury. Jednakże, w innych przypadkach, jest to nieuzasadnione $\mathrm{z}$ ekonomicznego punktu widzenia, dlatego też zamiast tego często wykorzystuje się podziemne lub częściowo podziemne bezpieczne przestrzenie (Movahedinia [5]).

Zarządzanie projektem to zorganizowany system służący do zarządzania zasobami, dzięki czemu projekt może być ukończony zgodnie z określoną wizją w zakresie jakości, czasu i kosztu (Burke [7]). Projekty budowlane, podobnie jak inne działania i projekty, posiadają swoje własne ograniczenia. W odniesieniu do zarządzania projektem, są to tradycyjnie ograniczenia zakresu, czasu i kosztu. Te trzy czynniki są również określane jako trójkąt zarządzania projektem, w którym każde ograniczenie określa jedną stronę trójkąta. Podobnie jak w geometrii, jeśli jedna strona ulegnie zmianie, inne strony również się zmieniają; w zarządzaniu projektem, zmiany jednego czynnika wpływają również na inne czynniki. Trójkąt zarządzania projektem można również stosować w relacjach czasu, kosztu i jakości (Clements i Gido [8]). Oznacza to, że każdy projekt posiada trzy ograniczenia, którymi są czas, koszt i zakres.

Ogólnie rzecz biorąc, kwestia równoważenia kosztu, czasu i jakości jednocześnie stara się uwzględnić trzy ważne czynniki w zarządzaniu projektem. Łatwo zrozumieć, że kwestia ta ma charakter wieloczynnościowy i może być przedstawiana w postaci modeli o wielu celach (Shuquan i Kongguo [11]). Struktura takiego modelu zawiera wiele opcji dla każdego działania, a model próbuje wybrać te z minimalnym koszem i czasem oraz najwyższą maksymalną jakością, lecz w tym przypadku mamy do czynienia z równoważeniem selekcji, ponieważ wysoka jakość i szybkość mają swoją cenę, a wykonanie kosztownego projektu może nie być możliwe. Badanie to ma na celu modelowanie problemu równoważenia kosztu, czasu i jakości w formie problemu o wielu celach, a następnie jego rozwiązanie za pomocą meta-heurystycznych algorytmów.

Algorytm genetyczny: W tym algorytmie wykorzystuje się historyczne dane w oparciu o jego dziedziczną naturę. W matematycznym modelu metod genetycznych, każdy z operatorów genetycznych jest symulowany, a ich połączenia określają naturalny proces wyboru najlepszego rozwiązania. W tej metodzie, próbka wszystkich zmiennych związanych z podejmowaniem decyzji, które wpływają na funkcję celu, jest traktowana jako element, w którym niektóre z tych próbek tworzą zbiór elementów i noszą nazwę generacji próbnej w zmiennych przestrzeniach. Następnie, poprzez 
wykonywanie operatorów genetycznych na elementach i początkowej generacji, powstaje nowa generacja o lepszych cechach. Powtarzanie tego procesu przez kilka generacji spowoduje powstanie najodpowiedniejszej generacji, co stanowi optymalne rozwiązane. Poprzez matematyczną symulację i ewolucję operatorów genetycznych w kompleksowym poszukiwaniu szeregu rozwiązań na przestrzeni pokoleń, otrzymuje się najdoskonalszą próbkę, która daje najlepszą optymalizacją funkcji celu spełniającego ograniczenia (Deb, i in. [13]).

Model opisany w tej części opiera się na planowaniu całkowitym. W tym modelu, dla każdego działania możliwe są różne metody wykonawcze oparte na kombinacji materiałów i nakładu pracy. Te różne metody wykonawcze będą charakteryzowały się innym czasem, kosztem i jakością.

Aby móc skorzystać z modelu, musi on zostać wdrożony, w związku z czym podjęto studium przypadku w celu zaplanowania bezpiecznej przestrzeni podziemnej. Plan budowy dotyczący żelbetonowych konstrukcji podziemnych obejmuje planowanie i projektowanie przed rozpoczęciem procesu realizacji.

Pożądane parametry w zakresie projektowania bezpiecznej przestrzeni podziemnej na dużą skalę zostały podzielone na następujące kategorie: Dostęp, wejścia i wyjścia, ergonomia, autonomia bezpiecznej przestrzeni, możliwość przywrócenia, bezpieczne systemy gaszania pożaru, szczegółowe informacje wykonawcze, wentylacja i filtracja, architektura wnętrz projektu i struktury.

W celu opracowania modelu optymalizacji bilansu kosztów, czasu i jakości, należy oszacować standardowe i intensywne wartości tych parametrów. Ponadto, należy określić wszystkie dostępne, intensywne formy działań. W związku z tym, powołano grupę pięciu ekspertów budowlanych, w celu opracowania kilku metod realizacji, a dla każdej takiej metody określono parametry dotyczące standardowych i intensywnych wartości czasu, kosztu i jakości. Dane zostały zebrane podczas szeregu spotkań i wywiadów z ekspertami.

W celu rozwiązania tego problemu, zastosowano algorytm meta-heurystyczny NSGA-II, jak również matematyczne oprogramowanie obliczeniowe i programistyczne MATLAB. Po zakończeniu obliczeń i modelowania kodu, uzyskano wyniki optymalizacji.

Projekty infrastrukturalne wymagają dużej ilości zasobów i nakładu kosztów. Warunkiem powodzenia każdego projektu jest spełnienie określonych wartości dla trzech czynników: czasu, kosztu i jakości, co oznacza ukończenie projektu w określonym czasie, po określonych kosztach i zapewniając określoną jakość, a przekroczenie tych limitów może spowodować niepowodzenie. Aby uzyskać optymalną równowagę pomiędzy tymi trzema czynnikami projektu, w badaniu zastosowano modelowanie matematyczne, które jest modelem o wielu celach i ma trzy główne założenia. Pierwszym założeniem jest organiczenia czasu trwania projektu. Drugim założeniem jest zmniejszenie całkowitego kosztu projektu, natomiast trzecim jest maksymalizacja jakości projektu.

Wynik dotyczący wykorzystania takiego modelu dowodzi, że dla niektórych działań wybiera się pierwszy, a dla innych drugi tryb wykonania i uzyskuje optymalny czas dla każdego działania, który mieści się pomiędzy standardową wartością i intensywną wartością.

Zgodnie z wynikami tego badania, dla przyszłych prac zaproponowano poniższe obszary badań:

- Zastosowanie nowszego i bardziej wydajnego algorytmu meta-heurystycznego w celu osiągnięcia krótszego czasu na rozwiązanie problemu i obliczenie kodu, np. potężny algorytm ewolucyjny Pareto SPEA-II

- Optymalizacja czasu, kosztu i jakości projektów z umowami EPC. 